EXEMPLARIa Classica

Journal of Classical Philology

18, 2014, pp. 73-79

ISSN 1699-3225

\title{
SOME NEW IMITATIONS OF ACHILLES TATIUS IN THE $\varepsilon$ RECENSION OF THE ALEXANDER ROMANCE
}

\author{
STEPHEN M. TRZASKoma \\ The University of New Hampshire \\ s.trzaskoma@unh.edu
}

SUMMARY

This note explores further the connections between Achilles Tatius' Leucippe and Clitophon and the $\varepsilon$ recension of the Alexander Romance noted earlier by Jouanno, adds several examples of verbal imitation, and suggests emending $\alpha \lambda \lambda$ '

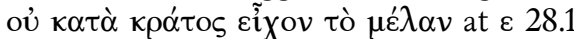

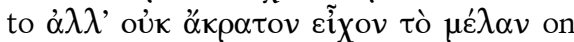
the basis of the model of the novelistic hypotext.

KEYWORDS

Achilles Tatius, Alexander Romance, intertextuality.
RESUMEN

En esta nota se profundiza en la conexión entre la novela Leucipe y Clitofonte de Aquiles Tacio y la recensión $\varepsilon$ del romance de Alexandre apuntada antes por Jouanno, se añaden varios ejemplos de imitación verbal y se sugiere escribir $\dot{\alpha} \lambda \lambda^{\prime}$ oúk

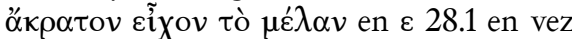

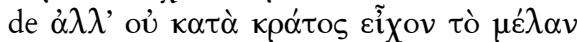
basándose en el modelo del hipotexto novelístico.

Palabras Clave

Aquiles Tacio, Romance de Alexandre, intertextualidad.

Fecha de recepción: 23/08/2013

Fecha de aceptación y versión final: 21/06/2014

The seventh and eighth centuries CE do not abound with known readers of the Greek novels, ${ }^{1}$ but thanks to the investigations of Corinne Jouanno, ${ }^{2}$ we now know that the author of the seventh- or eighth-century ${ }^{3} \varepsilon$ recension

${ }^{1}$ Which is not to say that they did not exist. The Codex Thebanus of Chariton, for instance, was produced in the sixth or seventh century according to U. Wilcken, "Eine neue Romanhandschrift", $A P F$ 1, 1901, 227-72, but because the codex was destroyed before its partial publication, we have no opportunity to reassess that dating.

${ }^{2}$ See C. Jouanno, Naissance et métamorphoses du Roman d'Alexandre, Paris 2002, 392-400, esp. 392-3.

${ }^{3}$ For the date, $c f$. Jouanno, Naissance, 339: "généralement datée de l'extrême fin du VII ${ }^{\mathrm{e}}$ siècle ou du début du VIII" ${ }^{\circ}$. 
of the Historia Alexandri Magni reworked the earlier versions of that text in a novelistic mode and took particular stylistic inspiration from Achilles Tatius' second-century Leucippe and Clitophon. ${ }^{4}$ She gives several examples

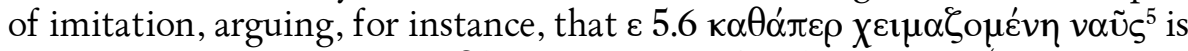

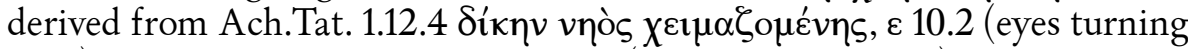
back) from Ach.Tat. 1.4.5, ${ }^{6}$ and $\varepsilon 36.5$ (the beauty of tears) from Ach.Tat. 6.7.1. These suggest "un emprunt direct", and, even if one does not find every instance entirely persuasive, ${ }^{7}$ the overall argument cannot be questioned. Moreover, it can be extended with further analysis both of passages she mentions and of several additional instances of imitation of the novel.

In terms of the first of these options, I will content myself here with exploring a bit more only one of the passages above, $\varepsilon 10.2$, in which the Persian messengers catch sight of Alexander for the first time:

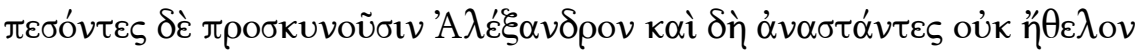

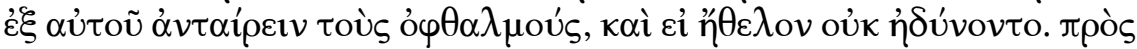

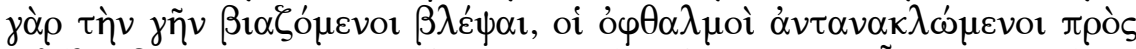

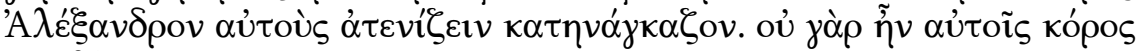

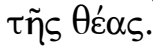

"Falling, they made obeisance to Alexander and when they got up they were not willing to lift their eyes from him-if they were willing, they were not able. For, though forced to look at the ground, their eyes, turning back, forced them to gaze upon Alexander. They had no satiety of looking”.

Jouanno draws our attention to several features of this passage, including the $\varepsilon$-recension author's use of the rare collocation ó $\varphi \theta \alpha \lambda \mu$ oì $\alpha \nu \tau \alpha v \alpha \kappa \lambda \omega \omega^{\prime} \mu \varepsilon v o t$

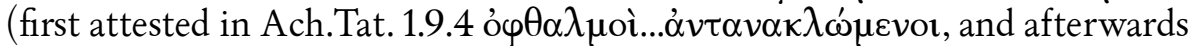
only here ${ }^{8}$ and elsewhere in the $\varepsilon$ recension at 2.24 in the active ỏ $\varphi \theta \alpha \lambda \mu$ oìs

${ }^{4}$ For Achilles Tatius I cite the text of J.-P. Garnaud, Achille Tatius d'Alexandrie: Le Roman de Leucippé et Clitophon, Paris $2002\left(=1991^{3}\right)$. For the $\varepsilon$ recension of the Alexander Romance I follow the edition of J. Trumpf, Vita Alexandrini Regis Macedonum, Stuttgart 1974.

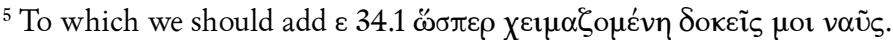

${ }^{6} \mathrm{I}$ treat this passage at greater length below.

7 Although I am convinced by Jouanno's arguments generally, there is some room to doubt whether the image of the ship, for example, must come from Achilles Tatius. $C f$., e.g.,

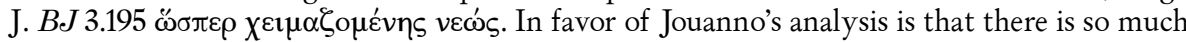
clear influence from Leucippe and Clitophon elsewhere. Thus, although it may have a wider presence in Greek literature, this does not necessarily mean that the $\varepsilon$-recension author did not take it from Achilles.

${ }^{8}$ To be thorough it should be said that it is also in the $y$ recension at 1.26 , which derives from this very passage of $\varepsilon$. 
$\dot{\alpha} \nu \tau \alpha \nu \alpha \kappa \lambda \alpha \dot{\alpha} \sigma \alpha \varsigma)$. There is a general resemblance to several novelistic motifs in the whole scene, particularly the semi-divine appearance of and reactions to Xenophon of Ephesus' Anthia and Habrocomes at the start of the Ephesiaca. However, as Jouanno argues, the passage resembles most clearly the scene in the first book of Achilles Tatius when Clitophon first glimpses Leucippe (Ach.Tat. 1.4.5):

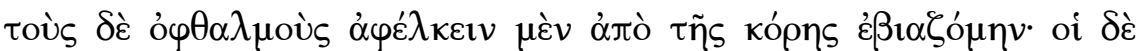

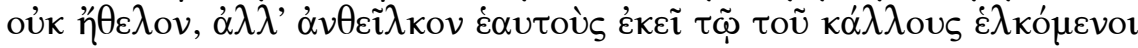

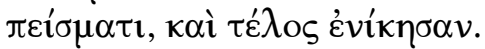

"I tried to pull my eyes away from the girl, but they were not willing. Instead they pulled themselves back to her, pulled by the persuasion of her beauty, and finally they won."

We have the thematic contexts of vision, of contrasting will and ability, of the eyes' mastery over their owners and other such connections, and it is hard to think the influence of Leucippe and Clitophon is not to be discerned here, especially when there is so much similarity of vocabulary in the two

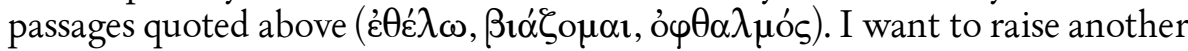
element from the novel that occurs in this passage that Jouanno does not draw out, namely Clitophon's self-description in the novel as sating himself

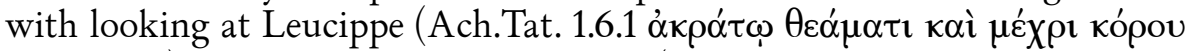

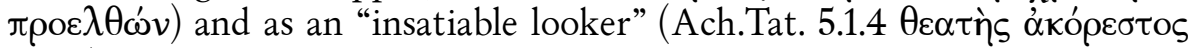

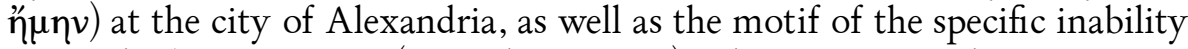
not to look at someone (cf. Ach.Tat. 2.1.1). This section in the Alexander Romance, then, is not just a reminiscence of a single passage from the novel but a stylistic pastiche arising from a thorough familiarity with the whole of it and a conscious attempt to eroticize the experience of looking at Alexander in novelistic terms. ${ }^{9}$

It is also possible to point out some further imitations that Jouanno does not mention and that I do not believe have been noted by others. First, we find the character Menelaus in Ach.Tat. 5.15.1, when he is parting ways with Clitophon and the rest of his company, described as:

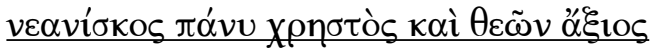

"a thoroughly excellent young man worthy of the gods"

\footnotetext{
${ }^{9}$ By this I do not mean to imply that Jouanno's argument is that the novelistic influence on the $\varepsilon$ recension is limited-quite the opposite. My point is that her general analysis (particularly Jouanno, Naissance, 393-5) deserves additional investigation and further elaboration.
} 
This language, precisely paralleled nowhere else, is transferred by the $\varepsilon$-recension author $(\varepsilon 5.7)$ to Alexander when he is reluctant to part company with Laomedon in Rome:

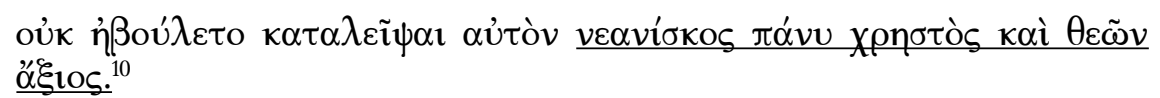

"Being a thoroughly excellent young man worthy of the gods, he was unwilling to leave him behind."

To take another instance, Achilles' novel begins with a frame narrator's arrival in Sidon, where he tours the city and does a bit of sightseeing of the temple offerings (1.1.2):

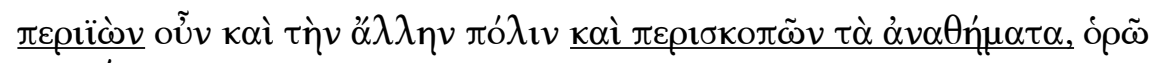

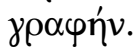

"Then I, while going around the rest of the city and examining the dedications, saw a painting."

Compare the $\varepsilon$-recension's description of Alexander's actions when he conquers Thebes $(\varepsilon 12.7)$ :

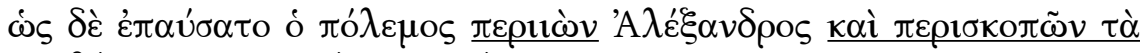

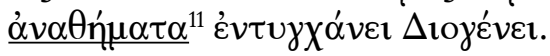

"When the war was over, Alexander, while going around and examining the dedications, encountered Diogenes."

In both cases the language in this form does not appear elsewhere in earlier Greek literature or in the earlier recensions of the Alexander Romance and is the particular contribution of the $\varepsilon$ recension author. There are also additional connections, and the $\varepsilon$ recension frequently shows such small touches of the stylistic influence of Achilles Tatius, many of which are too slight to mention in a convincing way here, but which are sometimes quite

${ }^{10}$ The imitation confirms that this text, that of MS Q, which is printed by Trumpf, Vita, is correct. The other manuscripts show some slight variation, as does the derivative $\gamma$ recension.

${ }^{11}$ It may be objected that the MSS of the $\varepsilon$ recension do not contain the words kai $\pi \varepsilon \rho \iota \sigma \kappa о \pi \tilde{\omega} v \tau \dot{\alpha} \alpha \dot{\alpha} \alpha \theta \dot{\eta} \mu \alpha \tau \alpha$, which are restored from the $\gamma$ recension, but since the author of the $\gamma$ recension was working from $\varepsilon$ at this point and no other source, and since he elsewhere introduces no independent imitations of Achilles Tatius, we can have some confidence that Trump, Vita, was right to restore and print the words here even if he was unaware of the imitation. 
clear, as in the description of the terrible women in $\varepsilon 25.2$ :

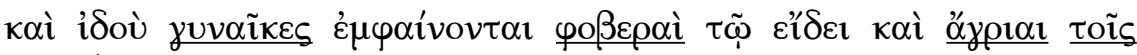

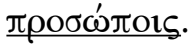

"And suddenly women appeared, fearsome to look at and savage in their faces."

It seems to me that this must owe something to the description of Hecate in Leucippe and Clitophon 1.3.4:

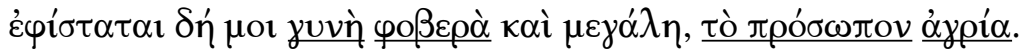

"Then a fearsome and large woman appeared to me, savage in her face."

The subject of Achilles' influence on the author of this recension, then, requires more systematic study. For once we definitively establish that the author of the $\varepsilon$ recension knew Achilles and took him as a stylistic model, possible examples of this imitation begin to look more convincing and less

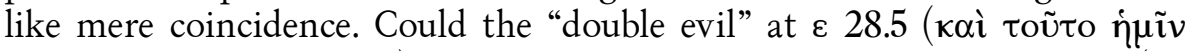

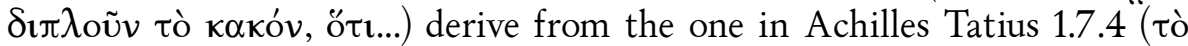
кakòv $\delta ı \pi \lambda \circ \tilde{v} v)$ ? The phrase is not unknown elsewhere in Greek, but it is rare. Almost certainly the description of the garden on the Isle of the Blessed owes something to Achilles, as we can be reasonably sure from a

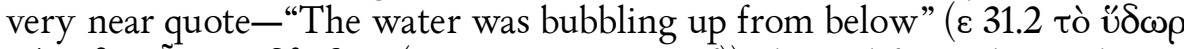
$\kappa \alpha \dot{\tau} \omega \theta \varepsilon v \tilde{\hat{\eta}} v \dot{\alpha} v \alpha \beta \lambda \tilde{u} \zeta o v$ (sic accent. Trumpf)), derived from the garden in the painting of Europa in Leucippe and Clitophon 1.1.5, "water...some of

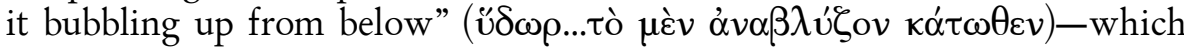
sits amidst several vaguer resemblances. ${ }^{12}$ It is possible to quibble over such instances, but it seems increasingly likely that Achilles is behind at least some of them. This, in turn, lends support to Jouanno's conclusion that novelistic influence is so pervasive that "toute l'écriture du récit est travaillé de tendances romanesques."13

I will conclude with one final example that I consider certain and of particular interest because it helps us restore the correct text of $\varepsilon$. In $\varepsilon 28.1$ Alexander and his troops meet wild men who are described in the following terms:

\footnotetext{
${ }^{12}$ I generally refrain throughout this discussion from noting less clear parallels between the

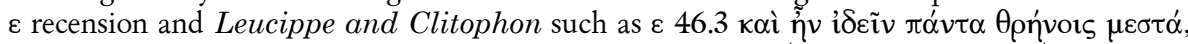

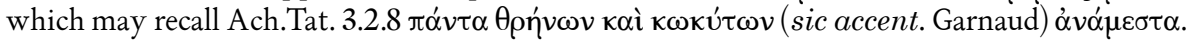

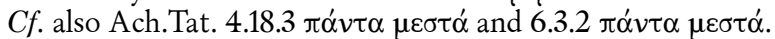

${ }^{13}$ Jouanno, Naissance, 393.
} 


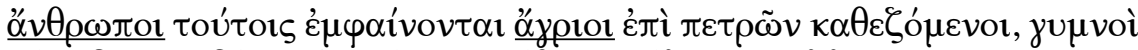

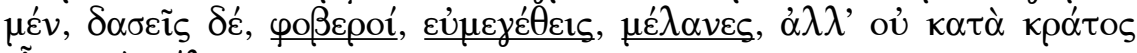

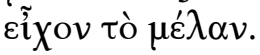

"Wild men appeared to them sitting on the cliffs. They were naked but shaggy, fearsome, large, and black-but they did not have their black forcefully."

With this we may compare the description of the Egyptian Boukoloi in Leucippe and Clitophon (Ach.Tat. 3.9.2) and note its identical term for them ("丷ypror ö $v \theta \rho \omega \pi \mathrm{or})$ and its matching emphasis on their size, fearsomeness, and dark color:

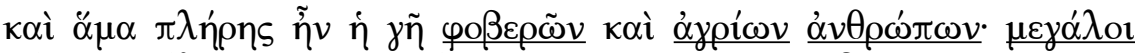

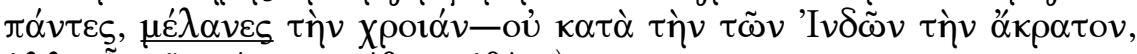

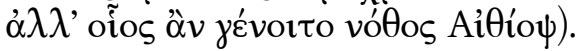

"And at once the land was full of fearsome and wild men. They were all large and black in color-not the unmixed black found among Indians but like a half-breed Ethiopian would be.”

The difficulty lies in the fact that in the transmitted text of the Romance

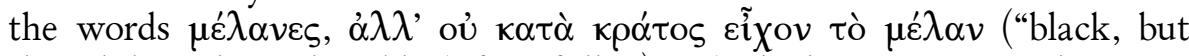
they did not have their black forcefully") make little sense. One rather poor solution is that adopted by the author of the derivative $\gamma$ recension, who, not understanding what was presumably the already corrupted text before

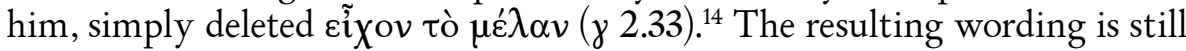
strained $^{15}$ and ill fits the context of the vicious and powerful attack of the savages that follows.

The interest in refining the description of the color of the Boukoloi displayed by Achilles Tatius throught his use of the word ökpotov shows us the way; for it contains a stylistic tic of the novelist-namely the literary use of ókpatos with color terms, ${ }^{16}$ which is earlier limited to technical

${ }^{14} \mathrm{H}$. Engelmann, Der Griechische Alexanderroman Rezension $\Gamma$. Buch II, Meisenheim am Glan 1963 reports the manuscripts of $\gamma$ are unanimous here.

${ }^{15}$ It could-presumably-just barely mean "black, but not strong” as R. Stoneman, The Greek Alexander Romance, London 1991, 176, translates it.

${ }^{16}$ It is used three times in the novel in the sense "pure of color". See J. N. O'Sullivan, $A$

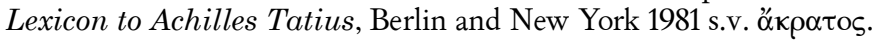


writing $^{17}$-and is imitated by others elsewhere, including Aristaenetus. ${ }^{18}$ Aristaenetus shows us the novel's usage was thought of as memorable and distinctive. In the case both of the author of the $\varepsilon$ recension and Aristaenetus, the underlying source passage is in Leucippe and Clitophon 1.4.3, where we get a description of Selene in a painting, including the words ó $\varphi \rho \grave{s} \mu \varepsilon \dot{\varepsilon} \lambda \alpha \imath v \alpha$,

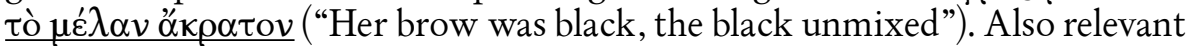
to our current passage of the Alexander Romance is the language in Ach. Tat. 3.7.4. There we have a different color but precisely the construction we

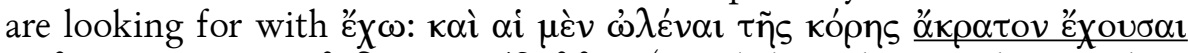

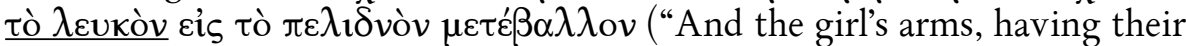
white unmixed, were becoming livid"). The $\varepsilon$ recension author knew Achilles Tatius' style thoroughly and, as elsewhere, combines elements from separate portions of the novel into a single imitation. ${ }^{19}$

It is possible that the corruption in $\varepsilon$ is deeper, but the simplest solution

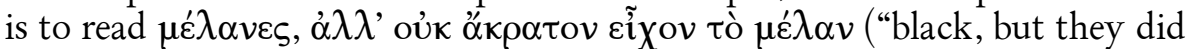
not have their black unmixed" or, more naturally, "black, but they were not pure black"). The wild men, then, are in terms of color just like the Boukoloi in the novel. Presumably, the sequence oúk ök $\rho \alpha \tau$ ov was wrongly divided ou $\kappa \alpha$ - in the eye and mind of some copyist, ${ }^{20}$ and perhaps the sequence $\kappa \alpha$ suggested an abbreviation of $\kappa \alpha \tau \alpha$. It is not great leap, then, to imagine a conscious or unconscious adjustment of the resulting ungrammatical $\kappa \alpha \tau \grave{\alpha}$

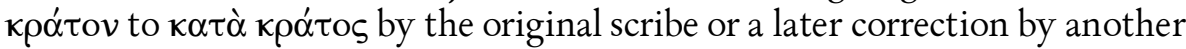
one. $^{21}$

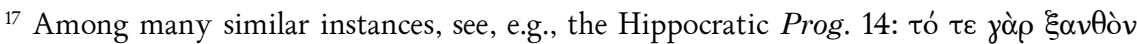

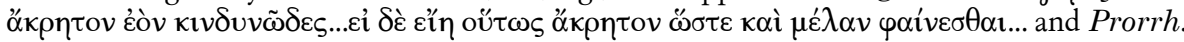

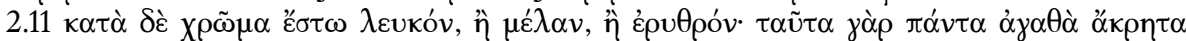

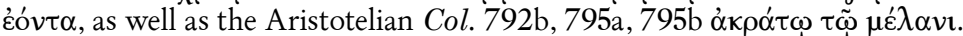

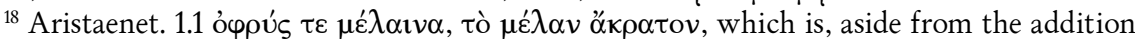
of $\tau \varepsilon$, a verbatim citation of Ach.Tat. 1.4.3 (see just below) and is embedded in a larger series of imitations of that passage.

${ }^{19} C f . \varepsilon 10.2$, for instance, which is discussed by Jouanno, Naissance, 392-3 with n. 415 , where we have elements from Ach.Tat. 1.4.5 and 1.9.4 combined.

${ }^{20} \mathrm{My}$ impression, without having made a careful study of the phenomenon, is that while errors of word division are quite frequent, this precise sort of corruption is rather less common than its opposite, namely, the mistake of oủ + vowel for a correct ou $\kappa+$ vowel. For instance, in the manuscripts of Achilles Tatius at 3.18 .1 we find variation between oú $\kappa \rho \alpha \tau \tilde{\omega}$ and oủ $\dot{o} \rho \tilde{\omega}$, where the former is correct and the latter an adjustment, and at 4.7 .8 we have the correct

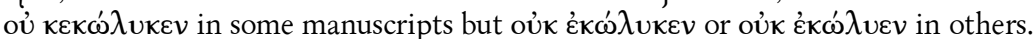

${ }^{21}$ I would like to express my gratitude to Exemplaria Classica's two referees for their comments and suggestions.
} 
